FACULTAD DE CIENCIAS ECONÓMICAS Y EMPRESARIALES

\title{
COMPLUTENSE
}

MADRID

\section{THE EFFECT OF HIGH-TECH SERVICES OFFSHORING ON SKILLED EMPLOYMENT: INTRA-FIRM EVIDENCE}

Mery Patricia Tamayo

Elena Huergo

Working Papers / Documentos de Trabajo. ISSN: 2255-5471

DT CCEE-1306 Mayo 2013

http://eprints.ucm.es/21751 


\title{
THE EFFECT OF HIGH-TECH SERVICES OFFSHORING ON SKILLED EMPLOYMENT: INTRA-FIRM EVIDENCE
}

\begin{abstract}
:
The offshoring of high-tech services has greatly increased in recent years, with consequences for firms demand for skilled employment in firms. This paper specifically analyzes the relationship between $R \& D$ offshoring and the demand for $R \& D$ employment using firm-level data for Spanish manufacturing and services companies during the period 2004-2009. Estimating different specifications with panel data techniques, we find that this association is statistically positive. In particular, if R\&D offshoring doubles, the demand for researchers will raise by about $8 \%$.
\end{abstract}

Keywords: R\&D offshoring; wages; Skilled employment.

\section{EL EFECTO DEL OFFSHORING DE SERVICIOS DE ALTA TECNOLOGÍA SOBRE EL EMPLEO CUALIFICADO: EVIDENCIA INTRA-EMPRESA}

\begin{abstract}
Resumen:
Este trabajo analiza la relación entre el offshoring de I+D y la demanda de investigadores utilizando datos de empresas españolas manufactureras y de servicios durante el período 2004-2009. A partir de la estimación de una ecuación de demanda de investigadores con técnicas de datos de panel, encontramos que esta asociación es estadísticamente positiva. En particular, los resultados sugieren que si las empresas duplicaran sus compras de servicios de $\mathrm{I}+\mathrm{D}$ en el extranjero, su demanda de investigadores aumentaría alrededor del 8\%.
\end{abstract}

Palabras clave: Offshoring de I+D; Salarios; Empleo cualificado.

Materia: Demanda de trabajo.

JEL: F16, L24, 03.

\section{Mery Patricia Tamayo}

Universidad EAFIT and GRIPICO-UCM

Grupo de Economía y Empresa, Departamento

de Economía, Universidad EAFIT, carrera 49

No 7 sur - 50, Medellín, Colombia.

E-mail: mptamayo@eafit.edu.co
Elena Huergo

GRIPICO-UCM

Dpto. Fundamentos del Análisis Económico I. Facultad de CC. Económicas y Empresariales. Universidad Complutense de Madrid. 28223 Madrid. España.

E-mail: ehuergo@ccee.ucm.es.

Mayo 2013 (fecha de recepción)

This research has been partially funded by the CICYT project ECO2010-19847. The authors are particularly grateful to María García-Vega for useful comments.

Este trabajo ha sido editado por la Biblioteca de la Facultad de CC Económicas y Empresariales de la UCM, de acuerdo con los requisitos de edición que figuran en la Web institucional. Las opiniones expresadas en este documento son de exclusiva responsabilidad de los autores. 


\section{Introduction}

The frequency with which companies have made use of offshoring strategies has greatly increased in recent years (OECD, 2010). Although initially offshoring referred mainly to intermediate manufacturing goods, over the last decade, the offshoring of manufacturing goods has taken a back seat to the offshoring of services, since the demand for more advanced services in technical and administrative areas has substantially grown (Jensen, 2009; Metters and Verma, 2008).

As a consequence, standardized activities of unskilled workers in manufacturing industries have ceased to be the only subject of offshoring and, nowadays, the comparative advantage of countries is not only be associated with natural or physical capital, but also with human capital. Some countries are specializing in technological jobs and in the development of computational concepts, making offshoring a way to contract the necessary services for domestic production in other countries, improving delivery times and the capacity for interaction, and without having in many cases to transport any physical goods.

However, the increase in the offshoring of highly technological services has not happened without problems. When a white-collar worker, who is usually better paid because of her experience in ICTs and her ability to learn, is "relocated", some specific knowledge of the company is destroyed. As a result of the absence of valuable human capital, the incentives of administrators and employees to invest in gaining such specific knowledge diminish (Trefler, 2005).

Offshoring of high-tech tasks leads to more frequent separations between workers and companies, destroying important dimensions of human capital. It is not clear whether the loss of knowledge that arises from the separation of the company and the workers is an issue of equity, given that it can be harmful for workers displaced by offshoring, or a matter of efficiency, since it destroys valuable human capital.

In this context, many researches have focused on analyzing how materials and services offshoring affect the demand for skilled and unskilled workers, or on their impact on 
wages and welfare. Although the majority of these studies are done on a per-country and industry basis, recent studies have attempted to distinguish between different levels of education and occupations, suggesting in general that services offshoring generates a positive effect on employment and wages for skilled workers and the opposite for unskilled workers (Crinò, 2010).

The objective of our study is to contribute to the debate by analyzing the intra-firm impact of offshoring on the demand for one of the most qualified workers: researchers involved in R\&D activities. For this purpose, we use the information of Spanish firms available for the period 2004-2009 from the Panel of Technological Innovation PITEC, created by the INE (the Spanish Institute of Statistics) on the basis of the annual Spanish responses to the Community Innovation Survey (CIS). Due to rising unemployment in Spain in recent years, now it is essential to emphasize the discussion about the changes needed to achieve sustained long - term growth. According the OECD (2011), Spain needs to create policies to increase productivity, encourage greater investment in innovative sectors, and channel investment into human capital. This is important in order to continue diversifying production and maintaining support for processes such as the internationalization of Spanish enterprises.

The specific contribution of our study is twofold: Firstly, we analyze a particular type of offshoring: the purchases of R\&D services ${ }^{1}$ that domestic firms contract from foreign providers. These highly technological activities may have a stronger effect on the demand for skilled labor. Just as Markusen (2005) states, white-collar services that are marketed are crucial complements for different elements of the production chain, such as between skilled labor and the telecommunications and infrastructure teams. Furthermore, Crinò (2010) emphasizes that white-collar workers employed in services activities usually do good work and receive high wages. This work requires a high level of knowledge, and although in the past they were protected from offshoring, currently they are more exposed to it.

\footnotetext{
${ }^{1}$ R\&D services are defined in our database as: "Creative work to increase the volume of knowledge and to create new or improved products and processes (including the development of software)". They include, among others, engineering services, clinical tests or designs.
} 
Secondly, we use individual firm-level data and therefore the effects of offshoring are quantified within the firms that undertake this offshoring. This differs from many other studies in this field that use aggregate data for countries or industries or information about occupations. In addition, the panel structure of our database allows the use of suitable econometric methods to control for the heterogeneity of firms.

Our results suggest the existence of a positive relation between $R \& D$ offshoring and skilled employment for Spanish firms, providing evidence in favor of their complementarity. In addition, we find that this association is stronger in the services sector than in the manufacturing sector.

The study has the following structure. In Section 2, we summarize the previous literature about the relations between outsourcing, offshoring and skilled labor. Section 3 includes a description of the empirical model, the database and the main variables. In Section 4, we present the results and, finally, in Section 5, we conclude.

\section{Outsourcing, offshoring and skilled labor: State of the art}

Literature analyzing the impact of international outsourcing on labor markets has increased parallel to the process of globalization. From a theoretical point of view, an important group of papers follow a Helpman and Krugman (1985) style two-sector general equilibrium model of trading countries to identify the forces that can lead to increased outsourcing. These studies are a usual theoretical reference in the field of international economics.

An example is the model of two countries, North and South, developed by Glass and Saggi (2001). They assume that international outsourcing in basic production is developed in low-income countries, while northern firms import components that are used to finish the production in the north with northern workers. A manufactured good is produced (by international outsourcing in the south) with continuous intermediate goods that differ in the use of skilled and unskilled workers. All other goods are produced in the north. In the model, southern firms perform outsourcing only in the basic production of old designs, but new developments and designs are produced in 
northern countries. Outsourcing is carried out because of technological differences and not differences in factor endowment (as in Feenstra and Hanson, 1996a).

In a similar context of two countries, Antrás and Helpman's model (2004) assumes the existence of heterogeneous final-good producers that choose ownership structures and locations for the production of intermediate inputs. The equilibrium depends on the wage differential between the North and South, on the ownership advantage in each of the countries, on the distribution of the bargaining power between final good producers and suppliers of components, and on the headquarter intensity of technology.

Also from a macroeconomic perspective, Grossman and Rossi-Hansberg (2008) argue that countries with different stages of development, different technologies and different factor endowments generate different factor prices. They wonder about how offshoring opportunities affect wages of different types of labor (unskilled labor and skilled labor). Production technology is specified in terms of tasks and each task requires the input of some single factor of production. The decision to perform tasks through offshoring depends on the difference between internal and external prices and communications technology. The model assumes that tasks can be performed remotely, so that the production of a good can be internationalized. ${ }^{2}$

Against the above-mentioned models, which allow for explaining the impact of offshoring on labor markets from macroeconomic models, a second group of studies tries to analyze the same problem from a microeconomic perspective. These studies usually include empirical approximations made with data from a much larger level of disaggregation (firm, sector, occupation).

Many of these works have centered in analyzing whether the impact of outsourcing or offshoring is different for skilled workers (Hijzen et al., 2005; Canals, 2006; Ekholm and Hakkala, 2006; Geishecker and Görg, 2008 and forthcoming). Although these studies show different analytic structures and levels of disaggregation of data, in general they find that highly skilled workers obtain a wage premium due to international outsourcing, which has raised the gap between the wages of skilled workers with respect

\footnotetext{
${ }^{2}$ Offshoring is costly in the sense that performing a task at a distance requires a greater factor input than if the task is performed nearby, and tasks differ in their costs of remote performance.
} 
to the wages of unskilled workers in recent periods. This suggests the existence of a complementary relationship between international outsourcing and skilled employment, although its significance depends on aspects such as the inter-industrial labor mobility and labor rigidity, which are also influenced by public policies on labor markets.

Within this second group of studies we want to emphasize the ones that include a microeconomic foundation. This is the case of the studies by Amiti and Wei (2006), Criscuolo and Garicano (2010), and Crino (2010), who begin with the existence of an enlarged production function in which offshoring or outsourcing is incorporated. Assuming that firms maintain an optimizing behavior, these authors reach a function of labor demand that will be the equation to be estimated in the empirical part. This will be the approach in our study, given the type of empirical approximation that we intend to do. ${ }^{3}$ However, we follow a firm level perspective instead of an industry perspective, and we aim to reach a greater specificity in the analysis of the relation between labor demand and offshoring, using the information about offshore R\&D activities of Spanish firms. The sector to which companies belong and the type of technology they use will be taken into account, distinguishing between skilled and unskilled workers and focusing specifically on the firms' demand for researchers to perform inside R\&D activities.

\section{Model and data}

\subsection{The model}

Given the type of information available in the PITEC database, our methodology consists of the estimation of a conditional labor demand function in which the offshoring appears as a key determinant. This approach is in line with many papers that, since Griliches $(1979,1995)$, estimate the impact of R\&D activities on productivity with firm-level data starting from a standard production function that is augmented with a kind of technological input. ${ }^{4}$ In our case, the firm-level production function is

\footnotetext{
${ }^{3}$ A more detailed exposition of the model is done in the next section.

${ }^{4}$ Griffith et al. (2006) follow this approach to provide evidence for technology sourcing from the U.S.. The OECD (2007) also uses a similar model to measure the impact on the demand for labour of outsourcing production abroad. The model is estimated using sectoral data for 12 OECD countries for years 1995 and 2000.
} 
augmented with offshoring and internal innovation activities. In particular, the production function for firm $i$ in industry $j$ is written as follows:

$$
Y_{i j}=A_{i j}\left(o s s_{i j}, i n n_{i j}\right) F_{i j}\left(L_{i j}^{R \& D}, L_{i j}^{O}, K_{i j}, M_{i j}, S_{i j}\right)
$$

where $Y$ represents the output that is a function of labor, $L=L^{R \& D}+L^{O}$, physical capital, $K$, materials, $M$, and services used as inputs, $S$. Notice that, as we are interested in analyzing the impact of R\&D offshoring on skilled labor, we distinguish between the researchers devoted to $\mathrm{R} \& \mathrm{D}$ activities, $L^{R \& D}$, which by definition are highly qualified workers, and other employees, $L^{O}$. A stands for the technical change, which is a function of the offshoring of services, oss and also of innovation activities developed domestically by the firm, inn.

As was previously mentioned, in this article our concept of service offshoring refers specifically to those activities in research and development carried out abroad, that is, purchases of R\&D services from foreign providers, which can be firms of the same group, firms outside the group, public institutions, universities, etc. We call this concept $R \& D$ offshoring, which is different from the innovation activities developed domestically by the firm ${ }^{5}$, which we denote by inn in equation (1).

As in Amiti and Wei (2006), we assume that the process of minimizing costs happens in two stages: in the first stage, the firm chooses the quantity of traditional inputs, while in a second stage it chooses the proportion in which it will import material and service inputs. ${ }^{6}$ We also suppose that all firms in the same industry face identical input prices, including imported inputs and physical capital. In this context, the conditional labor demand function for R\&D employees can be expressed as:

$$
L_{i j}^{R \& D}=\frac{g_{j}\left(w_{j}, o s s_{i j}, i n n_{i j}, Y_{i j}\right)}{A_{j}\left(o s s_{i j}, i n n_{i j}\right)}
$$

\footnotetext{
${ }^{5}$ In particular, this concept includes internal R\&D activities (regardless of the remuneration to researchers to avoid double accounting), domestic R\&D outsourcing and other innovation expenditures.

${ }^{6}$ In addition, the fixed cost of importing services and material inputs may vary by industry. As Amiti and Wei (2006) justify, the level of the sophistication of the inputs are different for each industry, and hence will involve different amounts of search costs to be imported.
} 
where $\boldsymbol{w}_{j}=\left(w_{j}^{R}, w_{j}^{O}, r_{j}, q_{j}^{m}, q_{j}^{S}\right)$ is the vector of input prices that correspond, respectively, to the wages of researchers, the wages of the rest of the employees, the rental rate on capital, and the prices for materials and service inputs.

As is common in the empirical literature (Hamermesh, 1993; Criscuolo and Garicano, 2010; Crinò, 2010), this equation of conditional labor demand will be estimated using the following log-linear specification:

$\ln L_{i j}^{R \& D}=\beta_{0}+\boldsymbol{\beta}_{\boldsymbol{w}}^{\prime} 1 \mathbf{n} \boldsymbol{w}_{\boldsymbol{j}}++\beta_{o s} \ln o s s_{i j}+\beta_{i n n} \ln i n n_{i j}+\beta_{Y} \ln Y_{i j}+\boldsymbol{\beta}_{x}^{\prime} \boldsymbol{X}_{\boldsymbol{i j}}+\varepsilon_{i j}$

where $\boldsymbol{X}$ stands for a vector of other control variables that will be explained afterwards and $\varepsilon_{i j}$ is the residual with the usual properties. In this conditional demand function, if $R \& D$ offshoring increases productivity, we would expect the offshoring to have a negative effect on the demand for $R \& D$ employment, since fewer inputs are needed to produce the same amount of output.

Alternatively, if we substitute in equation [2] for the firm's profit maximizing level of output, which is also a function of offshoring, the following demand function for R\&D labor would be obtained:

$$
L_{i}^{R \& D}=\frac{g_{j}\left(\boldsymbol{w}_{j}, \text { oss }_{i}, \text { inn }_{i j}, p_{i}\right)}{A_{j}\left(\text { oss }_{i}, \text { inn }_{i j}\right)}
$$

which in terms of the log-linear specification will be equivalent to:

$$
\ln L_{i j}^{R \& D}=\beta_{0}+\boldsymbol{\beta}_{\boldsymbol{w}}^{\prime} \ln \boldsymbol{w}_{\boldsymbol{j}}+\beta_{o s} \ln o s s_{i j}+\beta_{i n n} \ln i n n_{i j}+\beta_{p} \ln p_{i j}+\boldsymbol{\beta}_{x}^{\prime} \boldsymbol{X}_{i j}+\varepsilon_{i j}
$$

The way in which offshoring affects labor demand in this equation is not easily identifiable, and, furthermore, is one of the main questions we seek to answer in this study. In line with Amity and Wei's (2006) arguments, R\&D offshoring could affect the demand for researchers through three main channels:

1) A substitution effect through the price of imported services. A fall in that price would lead to a reduction in the demand for researchers if $R \& D$ labor and $R \& D$ services were substitutes. However, the effect could be the opposite if they are complements. 
2) A productivity effect if $R \& D$ offshoring leads to improvements in efficiency. Firms may produce the same quantity of a product with fewer inputs, reducing their demand for labor inputs.

3) A scale effect if, as R\&D offshoring makes the company more efficient and competitive, the demand for its product increases and, as a consecuence, the firm also hires more employees.

The net effect of $R \& D$ offshoring through these three channels will be captured in coefficient $\beta_{\text {os }}$. In our firm-level context, it is not easy to predict which effect will be the predominant effect and in fact this is one of the main questions we want to answer empirically in the study.

\subsection{Description of the database and main variables}

The empirical analysis is done with the information provided in the Panel of Innovation Technology (PITEC), from 2004 to 2009. This database is carried out by the INE (The Spanish Statistics Institute) and encloses micro-data on Spanish firms' innovation activities and their conditions for scientific research. Although the PITEC includes a sample of firms that do not undertake technological activities, given the objective of this study, we focus the analysis in the sample of innovative firms, that is, firms that have positive innovation expenditures during the period.

This database allows us to study offshoring activities for the highest knowledge intensive input: Research and Development (R\&D). The database provides information about the $R \& D$ done within the firm (in-house $R \& D$ ) or outside the firm through a contract or an agreement (external R\&D). Also, purchasing services may take place in Spain or abroad, and the suppliers may be firms of the same group, firms outside the group, public institutions, universities, etc. With this in mind, we use the term $R \& D$ outsourcing for the purchases of $\mathrm{R} \& \mathrm{D}$ services (without taxes) from firms or other organizations outside the group (if the company belongs to a group) and the term $R \& D$ offshoring (oss) for the purchases of R\&D services abroad, regardless of the location of the provider. International outsourcing will be part of both concepts. 
In our database, around 7\% of firms engaged in offshore R\&D activities during the period. In the manufacturing sector $R \& D$ offshoring is greater than in the services sector: $8 \%$ of manufacturing firms purchase R\&D services abroad, while for service firms this percentage is $5 \%$. Among $R \& D$ offshorers, around $74 \%$ belong to the manufacturing sector, while $26 \%$ belong to the services sector. These percentages remain rather constant over time.

In addition, the presence of $R \& D$ offshorers is higher in high and medium tech sectors (see Table 1). As Añón et al. (2010) point out, unlike low technology sectors, firms with high levels of capital intensity or large firms are more likely to offshore high-tech activities because of their ability to manage capital flows, cash flow, and benefits through other countries.

Table 1

R\&D offshoring by activity sector and technology class

\begin{tabular}{|c|c|c|c|c|}
\hline \multirow{2}{*}{ Activity } & \multirow[b]{2}{*}{ Technology class } & \multicolumn{3}{|c|}{ Number of observations } \\
\hline & & $\begin{array}{l}\text { Firms without } \\
\text { R\&D offshoring }\end{array}$ & $\begin{array}{c}\text { Firms with } \\
\text { R\&D offshoring }\end{array}$ & Total \\
\hline \multirow{3}{*}{ Services } & Low technology & $8,672(96 \%)$ & $319(4 \%)$ & 8,991 \\
\hline & High \& medium technology & $5,548(94 \%)$ & $378(6 \%)$ & 5,926 \\
\hline & Total & $14,220(95 \%)$ & $697(5 \%)$ & 14,917 \\
\hline \multirow{3}{*}{ Manufacturing } & Low technology & $10,216(94 \%)$ & $701(6 \%)$ & 10,917 \\
\hline & High \& medium technology & $12,712(91 \%)$ & $1,229(9 \%)$ & 13,941 \\
\hline & Total & $22,928(92 \%)$ & $1,930(8 \%)$ & 24,858 \\
\hline \multicolumn{2}{|r|}{ Total } & $37,148(93.4 \%)$ & $2,627(6.6 \%)$ & 39,775 \\
\hline
\end{tabular}

Source: Own calculation from the PITEC 2004-2009.

Notes: Percentages over the total in each row are shown between parentheses. See the correspondence of high and medium-tech activities and low activities and the two-digit NACE Rev.2 class in Annex 1.

The information included in the PITEC also allows for distinguishing which part of total employment in the firm corresponds to researchers devoted to R\&D activities. The term researcher refers specifically to professionals who work on the creation of new 
concepts, products or processes, methods and systems, and on the management of respective projects. ${ }^{7}$ This $R \& D$ employment $\left(L^{R \& D}\right)$ is our measure of high-skilled labor demand. In our sample, the demand for researchers from the years 2004 to 2009 is half in manufacturing firms half (3.6) of what it is in services firms (7.1).

As for wages, the average wage for researchers $\left(w^{R}\right)$ has been obtained from the PITEC as the quotient between total remunerations to researchers and R\&D employment. ${ }^{8}$ As can be seen in Table 2, regardless of the activity sector, the average wage of researchers is higher in firms with more than 200 employees that offshore R\&D activities. In particular, the highest salaries are obtained by researchers that work in large firms that offshore R\&D and operate in high \& medium-tech services sectors. In this case, the average wage is $47.5 \%$ higher when compared with workers in firms with similar features in the manufacturing sector.

Table 2

Average wages (in $€$ ) of researchers by offshoring strategy, activity and size

\begin{tabular}{|l|c|c|c|c|c|c|}
\hline & \multicolumn{3}{|c|}{$\begin{array}{c}\text { SMEs } \\
\text { (less than 200 employees) }\end{array}$} & \multicolumn{3}{c|}{$\begin{array}{c}\text { Large firms } \\
\text { (200 employees or more) }\end{array}$} \\
\hline & $\begin{array}{c}\text { All } \\
\text { firms }\end{array}$ & $\begin{array}{c}\text { Firms without } \\
\text { R\&D } \\
\text { Offshoring }\end{array}$ & $\begin{array}{c}\text { Firms with } \\
\text { R\&D } \\
\text { Offshoring }\end{array}$ & $\begin{array}{c}\text { All } \\
\text { firms }\end{array}$ & $\begin{array}{c}\text { Firms without } \\
\text { R\&D } \\
\text { Offshoring }\end{array}$ & $\begin{array}{c}\text { Firms with } \\
\text { R\&D } \\
\text { Offshoring }\end{array}$ \\
\hline Services & 46,078 & 45,793 & 51,189 & 63,570 & 62,727 & 77,522 \\
High \& medium-tech & 43,531 & 42,981 & 51,063 & 77,367 & 75,657 & 99,856 \\
\hline Manufacturing & 47,511 & 47,237 & 52,799 & 63,600 & 61,156 & 74,253 \\
High \& medium-tech & 48,928 & 48,599 & 54,535 & 64,676 & 63,792 & 67,688 \\
\hline Total & $\mathbf{4 6 , 9 3 7}$ & $\mathbf{4 6 , 6 5 0}$ & $\mathbf{5 2 , 3 4 0}$ & $\mathbf{6 3 , 1 1 0}$ & $\mathbf{6 1 , 1 9 2}$ & $\mathbf{7 4 , 5 4 8}$ \\
\hline
\end{tabular}

Source: Own calculation from database PITEC 2004-2009.

The definitions of the rest of the variables included in the theoretical model are as follows. Domestic innovation expenditures (inn) are obtained as the sum of in-house R\&D expenditures (excluding the remunerations to $R \& D$ employment), domestic R\&D outsourcing and other innovation expenditures (on acquisition of machines, services,

\footnotetext{
${ }^{7}$ We exclude technicians or assistants in administrative tasks associated with R\&D activities from this concept.

${ }^{8}$ We have used sectoral price indexes to homogenize the monetary magnitudes of different years. The year 2007 is considered the base year. In the case of wages, we use harmonized labor cost indexes by activity class provided by the Spanish Institute of Statistics.
} 
and equipment, acquisition of external knowledge, preparation for production and distribution, training, and introduction of innovations). For manufacturing firms, total output $(Y)$ is obtained as sales deflated using sectoral price indexes published by the Spanish Institute of Statistics ${ }^{9}$. Because there is no data in our database about total labor costs, as a proxy of the wages of other employees $\left(w^{O}\right)$, we use the average wage of technicians and assistants in administrative tasks associated with R\&D activities. These jobs have a lower level of qualification. It is assumed that product prices and the rest of the input prices are the same for all the firms in the same industry. This is equivalent to introducing sectorial dummies in the model. ${ }^{10}$

Additionally, as control variables we include dummy variables reflecting whether the firm is an exporter, belongs to a high or medium-tech activity sector, has more than $50 \%$ of foreign capital or is a large firm. As Bernand et al. (2007) point out, exporters are larger, more productive, more capital and skill-intensive and pay higher wages than non-exporters, and Mayer and Ottaviano (2008) suggest that FDI-makers perform better than exporters. In addition, in many countries there is a correlation between firms that import intermediate inputs and those that export (Bernand et al., 2007). Therefore, the exporting character of a firm will be indirectly reflecting the offshoring of intermediate manufacturing inputs, which is an omitted variable in our model since there is no information about it in the database.

As for firm size, following the theory of human capital (Hamermesh, 1980, 1993; Kremer 1993; Dunne and Schmitz, 1992), the most skilled workers would be employed by large firms due to aspects such as the complementarity between physical and human capital, the advantages of matching skilled workers with other skilled workers, and the better capacity to amortize fixed costs associated with the hiring of skilled employees. Furthermore, as efficiency wage models show, given that monitoring costs are higher in large firms, it would be preferable for them to hire skilled workers, pay good wages, and create good working conditions as a way to avoid the constant search for workers and as an incentive for employees to remain in the firm (Bulow and Summers, 1986).

\footnotetext{
${ }^{9}$ There are not any series of sectoral price indexes for services activities with the level of sectoral disaggregation needed for the analysis.

${ }^{10}$ When the model is estimated as a fixed effects model in panel data using a within-groups estimator, these dummies disappear.
} 
In Table 3, the descriptives of the main variables used in the estimations are shown. Near $62 \%$ of firms are exporters, with the percentage higher in the manufacturing sector higher than in the services sector. In addition, in almost $10 \%$ of firms the presence of foreign capital exceeds $50 \%$ of ownership.

Table 3

Sample averages of the main variables

\begin{tabular}{|c|c|c|c|}
\hline Variables & All Firms & $\begin{array}{c}\text { Manufacturing } \\
\text { firms }\end{array}$ & $\begin{array}{c}\text { Services } \\
\text { firms }\end{array}$ \\
\hline Domestic innovation expenditures (inn) (in logs) & 11.8 & 11.8 & 11.8 \\
\hline Exporter $^{\mathrm{d}}$ (\% observations) & 61.9 & 77.5 & 35.0 \\
\hline Foreign capital $^{\mathrm{d}}$ ( $\%$ observations $)$ & 10.7 & 13.2 & 6.5 \\
\hline High and medium-tech activity sector ${ }^{\mathrm{d}}$ (\% obs.) & 53.6 & 59.1 & 45.3 \\
\hline International technological cooperation (\% obs.) & 15.5 & 15.1 & 16.5 \\
\hline Large firm ${ }^{\mathrm{d}}$ ( $\%$ observations $)$ & 18.9 & 20.6 & 16.1 \\
\hline Output $(Y)$ (in logs) & - & 16.2 & - \\
\hline Proportion of foreign support for R\&D (\%) & 0.06 & 0.02 & 0.12 \\
\hline Quantity of foreign support for R\&D (in logs) & 0.04 & 0.01 & 0.08 \\
\hline R\&D employment $\left(L^{R \& D}\right)$ & 4.8 & 3.6 & 7.1 \\
\hline R\&D employment $\left(L^{R \& D}\right)($ in $\log s)$ & 0.36 & 0.21 & 0.62 \\
\hline R\&D offshorer ${ }^{\mathrm{d}}(\%$ observations $)$ & 6.9 & 7.7 & 5.3 \\
\hline R\&D offshoring (oss) (in logs) & 0.77 & 0.89 & 0.59 \\
\hline Total employment $(L)$ (n. of employees) & 236.7 & 180.7 & 340.4 \\
\hline Wages of researchers $\left(w^{R}\right)($ in logs $)$ & 10.6 & 10.7 & 10.6 \\
\hline Wages of other employees $\left(w^{O}\right)$ (in logs) & 8.0 & 8.3 & 7.4 \\
\hline Number of observations & 33,134 & 20,893 & 11,920 \\
\hline
\end{tabular}

Source: Own calculation from the PITEC 2004-2009.

Note: ${ }^{\mathrm{d}}=$ dummy variable

\section{Results}

In this section, we present the evidence obtained from the estimation of the labor demand function in equation [5]. Because of the log-linear specification of the demand function, estimated coefficients of continuous explanatory variables can be interpreted as elasticities. 
Given the panel structure of the data, we have estimated the model, alternatively assuming alternatively a fixed effects (FE) model and a random effects (RE) model, and we use a Hausman specification test to choose among them. As it is well known, in the FE model the distribution of unobserved heterogeneity is not restricted, and nothing is assumed regarding the correlation structure between the individual effects and the explanatory variables, as the formers are treated as parameters to be estimated differently for each firm. However, in a random effects model assumptions must be made about the distribution of unobserved heterogeneity, and this is difficult to establish especially when the unobservable effects are correlated with other explanatory variables.

In our estimates, the coefficients of the FE model have been obtained using a withingroups estimator, while the coefficients of the RE model come from a Generalized Least Squares (GLS) estimator. In both cases, we previously test the normality assumption of errors, so that there exist heteroskedastic and first order autocorrelation. ${ }^{11}$ To correct these problems we calculate panel-corrected standard error (PCSE) estimates. ${ }^{12}$

In addition, notice that to develop the theoretical model we have assumed that the firm minimizes costs in two stages: first, it chooses the quantity of traditional inputs, and afterwards chooses the proportion in which it will import material and service inputs. However, these decisions could be simultaneous. To control for the potential endogeneity of R\&D offshoring, we also estimate the model using instrumental variables approaches. In particular, we consider two supplementary variables as instruments: a dummy variable capturing the existence of technological agreements with foreign partners (international technological cooperation), and the percentage of internal R\&D expenditures financed by foreign companies (proportion of foreign support for $R \& D$ ). Sargan overidentification tests are used to see the validity of these instruments in each specification.

Table 4 reports the results of the FE and RE models without instruments, as well as the estimations with instrumental variables by FE two stage least squares (FE2SLS), by RE

\footnotetext{
${ }^{11}$ In all cases, a modified Wald test is used to assess whether there exist is heteroskedasticity, as being the null hypothesis of constant variance is rejected. Additionally, a Wooldridge test confirms the presence of first order autocorrelation. These tests are available from the authors upon request.

${ }^{12}$ We use the "xtpcse" command in Stata.
} 
two stage least squares (RE2SLS), and by Baltagi's error component two-stage least squares $(\mathrm{EC} 2 \mathrm{SLS})^{13}$, respectively, for all innovative firms.

Table 4

Demand for researchers (in logs). All innovative firms

\begin{tabular}{|c|c|c|c|c|c|}
\hline & $\begin{array}{l}\text { FE } \\
\text { (1) }\end{array}$ & $\begin{array}{l}\mathrm{RE} \\
(2)\end{array}$ & $\begin{array}{l}\text { FE2SLS } \\
\text { (3) }\end{array}$ & $\begin{array}{l}\text { RE2SLS } \\
\text { (4) }\end{array}$ & $\begin{array}{c}\text { EC2SLS } \\
(5)\end{array}$ \\
\hline R\&D offshoring (in logs) & $\begin{array}{c}\mathbf{0 . 0 0 9} * * * \\
(0.001)\end{array}$ & $\begin{array}{c}\mathbf{0 . 0 2 5} * * * \\
(0.002)\end{array}$ & $\begin{array}{c}\mathbf{0 . 0 7 8} * * * \\
(0.013)\end{array}$ & $\begin{array}{c}\mathbf{0 . 1 2 8} * * * \\
(0.011)\end{array}$ & $\begin{array}{c}\mathbf{0 . 2 3 9} * * * \\
(0.013)\end{array}$ \\
\hline $\begin{array}{l}\text { Domestic innovation expenditures } \\
\text { (in logs) }\end{array}$ & $\begin{array}{l}0.052 * * * \\
(0.002)\end{array}$ & $\begin{array}{l}0.124 * * * \\
(0.002)\end{array}$ & $\begin{array}{l}0.047 * * * \\
(0.002)\end{array}$ & $\begin{array}{c}0.061 * * * \\
(0.002)\end{array}$ & $\begin{array}{l}0.054 * * * \\
(0.003)\end{array}$ \\
\hline Wages of researchers (in logs) & $\begin{array}{c}-0.125^{* * *} \\
(0.006)\end{array}$ & $\begin{array}{c}-0.106^{* * *} \\
(0.006)\end{array}$ & $\begin{array}{c}-0.127 * * * \\
(0.005)\end{array}$ & $\begin{array}{c}-0.125 * * * \\
(0.005)\end{array}$ & $\begin{array}{c}-0.131 * * * \\
(0.006)\end{array}$ \\
\hline Wages of other employees (in logs) & $\begin{array}{c}-0.033 * * * \\
(0.001)\end{array}$ & $\begin{array}{c}-0.035^{* * *} \\
(0.001)\end{array}$ & $\begin{array}{c}-0.034 * * * \\
(0.001)\end{array}$ & $\begin{array}{c}-0.033^{* * *} \\
(0.001)\end{array}$ & $\begin{array}{c}-0.034 * * * \\
(0.001)\end{array}$ \\
\hline Large firm & & $\begin{array}{l}0.440 * * * \\
(0.015)\end{array}$ & & $\begin{array}{l}0.441 * * * \\
(0.028)\end{array}$ & $\begin{array}{l}0.380 * * * \\
(0.038)\end{array}$ \\
\hline Exporter & & $\begin{array}{l}0.091 * * * \\
(0.008)\end{array}$ & & $\begin{array}{c}0.147 * * * \\
(0.022)\end{array}$ & $\begin{array}{l}0.128 * * * \\
(0.030)\end{array}$ \\
\hline Foreign capital & & $\begin{array}{l}0.107 * * * \\
(0.016)\end{array}$ & & $\begin{array}{l}0.035 \\
(0.035)\end{array}$ & $\begin{array}{l}-0.073 \\
(0.047)\end{array}$ \\
\hline Malnufacturing_firm & & $\begin{array}{c}-0.217 * * * \\
(0.013)\end{array}$ & & $\begin{array}{c}-0.236 * * * \\
(0.029)\end{array}$ & $\begin{array}{c}-0.271 * * * \\
(0.039)\end{array}$ \\
\hline High and medium-tech manufact. & & $\begin{array}{l}0.258 * * * \\
(0.010)\end{array}$ & & $\begin{array}{c}0.235 * * * \\
(0.025)\end{array}$ & $\begin{array}{l}0.230 * * * \\
(0.034)\end{array}$ \\
\hline High and medium-tech services & & $\begin{array}{c}0.457 * * * \\
(0.018)\end{array}$ & & $\begin{array}{c}0.457 * * * \\
(0.032)\end{array}$ & $\begin{array}{c}0.443 * * * \\
(0.044)\end{array}$ \\
\hline Hausman (p-value) & & 0.000 & & 0.000 & 0.0000 \\
\hline Test of joint significance & 0.000 & 0.000 & 0.000 & 0.000 & 0.0000 \\
\hline $\begin{array}{l}\text { Sargan over-identification test } \\
\quad p \text {-value }\end{array}$ & & & $\begin{array}{l}\chi^{2}(1)=2.5 \\
0.114\end{array}$ & $\begin{array}{c}\chi^{2}(1)=4.9 \\
0.027\end{array}$ & \\
\hline Number of observations & 33138 & 33138 & 31718 & 33174 & 33174 \\
\hline
\end{tabular}

Source: Own calculation from the PITEC 2004-2009.

Notes: Estimated standard errors between brackets. Coefficients significant at: 1\%***, $5 \% \%^{* *}, 10 \%{ }^{*}$. All regressions include the constant. Hausman reports the $p$-value from a test under the null hypothesis that unobserved firm effects are uncorrelated with the regressors. The test of joint significance of the variables reports the p-value of a Wald test except in the case of the FE2SLS estimates, where the p-value corresponds to an F-test. The instruments used are: quantity of foreign support for $R \& D$ and international technological cooperation.

\footnotetext{
${ }^{13}$ Baltagi's EC2SLS, is a matrix- weighted average between 2SLS and FE2SLS, and therefore provides estimates for time invariant variables. See Baltagi (2008), chapter 7, section 7.1.
} 
When models without instrumental variables are considered (columns (1) and (2)), the Hausman test confirms the existence of a correlation between observable explanatory variables and individual firm effects, so the coefficients from the FE model are the consistent ones under the assumption of strict exogeneity of independent variables. However, as most control variables are time-invariant and disappear in the within estimator, we keep the results from the RE model to have an intuition about their impact on labor demand for researchers. ${ }^{14}$

In both cases, R\&D offshoring has a positive effect on the demand for researchers. However, as we have mentioned previously, we must be cautious when interpreting this result as a causal relationship between $R \& D$ offshoring and the demand for $R \& D$ labor: the estimated coefficient could be biased upward if they were simultaneously determined by the firm. Nevertheless, the estimates by instrumental variables procedures (columns (3) to (5)) confirm the existence of a positive relationship, with the elasticity being between 0.08 and 0.24 depending on the assumption about the errors. In particular, the coefficient of the FE2SLS model implies that if R\&D offshoring doubles, the demand for researchers will raise by about $8 \%$.

Therefore, for this specific type of highly qualified employment, the evidence about the impact of R\&D offshoring seems to suggest the existence of a positive association between R\&D employment and imported R\&D services. This is consistent with both the hypothesis that they are strategic complements, and the prevalence of a scale effect: an increase in offshoring would make the firm more efficient and competitive, increasing the demand for its product and for all types of employment. The result is also in line with previous empirical evidence that, with other levels of aggregation in the data, suggests that service offshoring increases high skilled employment (Crinò, 2010).

As for the rest of the variables, unsurprisingly the average wage of researchers has a negative impact on their demand, the elasticity near -0.13 . The wages of other employees also have a negative relation with the employment of researchers, although the magnitude of this elasticity is lower. Domestic expenses on innovation have a positive effect on R\&D employment, which is coherent with Trefler's (2005) views,

\footnotetext{
${ }^{14}$ We have also performed RE2SLS including industry dummies for 2-digit NACE Rev. 2 classes, and the main results remain unchanged. These estimates are available from the authors upon request.
} 
which indicates that in recent years there has been a rapid growth in services that involve simultaneously involve innovation, intensive processes in technology, and employment for white-collar workers.

All the control variables behave in accordance to the predictions of economic theory. When taking into consideration the variables that appear in the estimations by RE, we observe that exporters, companies in high and medium-tech sectors, especially in services activities, and multinational and large firms tend to hire more researchers. In addition, the dummy variable for manufacturing firms reflects that this kind of company demands less R\&D employment.

As has been previously argued, authors such as Jensen (2009) state that during the last decade, offshoring has been redirected from manufacturing to services. For that reason, in what follows the results are analyzed separately for the manufacturing sector and the services sector (see Tables 5 and 6). In both samples all explanatory variables keep in general their signs and significance in general with respect to previous estimates for all innovative firms.

In addition, when only firms in the services sector are analyzed, $R \& D$ offshoring shows a positive association with the demand for researchers, as the elasticity is higher than in the whole sample. In this case, if $R \& D$ offshoring doubles, the demand for researchers will raise by around 11\% (see column (3) in Table 5). Once again, this suggests that labor demand can be affected through the scale effect or that R\&D labor and imported R\&D services are complements inside the firm.

The same positive relationship is obtained in the sample of manufacturing companies (see Table 6). However, in this case the elasticity of R\&D employment to R\&D offshoring is half of what it is in services, showing that the demand for highly skilled labor is more sensitive to changes in offshoring in the latter sector, which is probably due to the nature of services offshoring that we are considering in this study. 
Table 5

Demand for researchers (in logs). Services firms

\begin{tabular}{|l|ccccc|}
\hline & FE & RE & FE2SLS & RE2SLS & EC2SLS \\
& $(\mathbf{1})$ & $\mathbf{( 2 )}$ & $\mathbf{( 3 )}$ & $\mathbf{( 4 )}$ & $\mathbf{( 5 )}$ \\
\hline Offshoring (in logs) & $0.013^{* * *}$ & $0.029^{* * *}$ & $0.106^{* * *}$ & $0.196^{* * *}$ & $0.360^{* * *}$ \\
Domestic innovation expenditures & $(0.003)$ & $(0.003)$ & $(0.032)$ & $(0.029)$ & $(0.036)$ \\
(in logs) & $0.073^{* * *}$ & $0.165^{* * *}$ & $0.066^{* * *}$ & $0.082^{* * *}$ & $0.070^{* * *}$ \\
Wages of researchers (in logs) & $(0.005)$ & $(0.005)$ & $(0.005)$ & $(0.005)$ & $(0.007)$ \\
& $-0.162^{* * *}$ & $-0.161^{* * *}$ & $-0.161^{* * *}$ & $-0.160^{* * *}$ & $-0.162^{* * *}$ \\
Wages of other employees (in logs) & $(0.013)$ & $(0.013)$ & $(0.010)$ & $(0.010)$ & $(0.014)$ \\
& $-0.041^{* * *}$ & $-0.042^{* * *}$ & $-0.041^{* * *}$ & $-0.040^{* * *}$ & $-0.040^{* * *}$ \\
Large firm & $(0.001)$ & $(0.002)$ & $(0.002)$ & $(0.002)$ & $(0.002)$ \\
& & $0.380^{* * *}$ & & $0.417^{* * *}$ & $0.485^{* * *}$ \\
Exporter & & $(0.029)$ & & $(0.055)$ & $(0.080)$ \\
& & $0.134^{* * *}$ & & $0.175^{* * *}$ & 0.121 \\
Foreign capital & & $(0.016)$ & & $(0.044)$ & $(0.063)$ \\
& & $0.057^{* * *}$ & & -0.078 & $-0.247^{*}$ \\
High and medium-tech sector & & $(0.033)$ & & $(0.084)$ & $(0.119)$ \\
& & $0.428 * * *$ & & $0.423 * * *$ & $0.415^{* * *}$ \\
Hausman $(p$-value) & & $(0.018)$ & & $(0.042)$ & $(0.060)$ \\
Test of joint significance & & 0.000 & & 0.075 & 0.000 \\
Sargan over-identification test & 0.000 & 0.000 & 0.000 & 0.000 & 0.000 \\
$\quad$ p-value & & & $\chi^{2}(1)=1.9$ & $\chi^{2}(1)=4.1$ & \\
Number of observations & & & 0.167 & 0.044 & \\
\hline
\end{tabular}

Source: Own calculation from the PITEC 2004-2009.

Notes: Estimated standard errors between brackets. Coefficients significant at: 1\%***, 5\%**, 10\%*. All regressions include the constant. Hausman reports the $p$-value from a test under the null hypothesis that unobserved firm effects are uncorrelated with the regressors. The test of joint significance of the variables reports the p-value of a Wald test except in the case of the FE2SLS estimates, where the $p$-value corresponds to an F-test. The instruments used are: quantity of foreign support for $R \& D$ and international technological cooperation. 
Table 6

Demand for researchers (in logs). Manufacturing firms

\begin{tabular}{|l|ccccc|}
\hline & FE & $\mathbf{R E}$ & $\mathbf{F E 2 S L S}$ & RE2SLS & EC2SLS \\
& $\mathbf{( 1 )}$ & $\mathbf{( 2 )}$ & $\mathbf{( 3 )}$ & $\mathbf{( 4 )}$ & $\mathbf{( 5 )}$ \\
\hline Offshoring (in logs) & $0.007^{* * *}$ & $0.024^{* * *}$ & $0.056^{* * *}$ & $0.094^{* * *}$ & $0.181^{* * *}$ \\
Domestic innovation expenditures & $(0.001)$ & $(0.002)$ & $(0.012)$ & $(0.010)$ & $(0.011)$ \\
(in logs) & $0.039^{* * *}$ & $0.099^{* * *}$ & $0.036^{* * *}$ & $0.051^{* * *}$ & $0.046^{* * *}$ \\
Wages of researchers (in logs) & $(0.002)$ & $(0.003)$ & $(0.002)$ & $(0.002)$ & $(0.003)$ \\
& $-0.107^{* * *}$ & $-0.080^{* * *}$ & $-0.110^{* * *}$ & $-0.105^{* * *}$ & $-0.111^{* * *}$ \\
Wages of other employees (in logs) & $(0.006)$ & $(0.006)$ & $(0.005)$ & $(0.005)$ & $(0.006)$ \\
& $-0.027^{* * *}$ & $-0.028^{* * *}$ & $-0.028^{* * *}$ & $-0.028^{* * *}$ & $-0.028^{* * *}$ \\
Large firm & $(0.001)$ & $(0.001)$ & $(0.001)$ & $(0.001)$ & $(0.001)$ \\
& & $0.482^{* * *}$ & & $0.520^{* * *}$ & $0.418^{* * *}$ \\
Exporter & & $(0.017)$ & & $(0.028)$ & $(0.040)$ \\
Foreign capital & & $0.060^{* * *}$ & & $0.121^{* * *}$ & $0.111^{* * *}$ \\
& & $(0.009)$ & & $(0.022)$ & $(0.030)$ \\
High and medium-tech sector & & $0.128^{* * *}$ & & -0.003 & $-0.045^{*}$ \\
& & $(0.017)$ & & $(0.018)$ & $(0.023)$ \\
Hausman ( $p$-value) & & $0.265^{* * *}$ & & $0.248^{* * *}$ & $0.247^{* * *}$ \\
Test of joint significance & & $(0.010)$ & & $(0.019)$ & $(0.025)$ \\
Sargan over-identification test & & 0.000 & & 0.000 & 0.000 \\
$\quad$ p-value & 0.000 & 0.000 & 0.000 & 0.000 & 0.000 \\
Number of observations & & & $\chi^{2}(1)=3.3$ & $\chi^{2}(1)=3.1$ & \\
\hline
\end{tabular}

Source: Own calculation from the PITEC 2004-2009.

Notes: Estimated standard errors between brackets. Coefficients significant at: 1\%***, 5\%**, 10\%*. All regressions include the constant. Hausman reports the $p$-value from a test under the null hypothesis that unobserved firm effects are uncorrelated with the regressors. The test of joint significance of the variables reports the p-value of a Wald test except in the case of the FE2SLS estimates, where the $p$-value corresponds to an F-test. The instruments used are: quantity of foreign support for $R \& D$ and international technological cooperation.

To study this question more deeply, estimates in Table 7 split the sample of services firms in two subsamples, one for firms operating specifically in the sector of Scientific research and development, and one for the rest of the services firms. ${ }^{15}$

According to this criterion, the results establish that the elasticity of R\&D employment to imported $R \& D$ services is larger when we exclude the firms in the R\&D sector from the analysis. However, in this latter industry, the association is much weaker and even

\footnotetext{
${ }^{15}$ For simplicity, in this case we only show the results obtained with IV procedures.
} 
disappears in the FE2SLS model. This suggests that for firms in R\&D activities the scale effect could be partially compensated by a substitution relation between both inputs.

Table 7

Demand for researchers (in logs). Services firms

\begin{tabular}{|c|c|c|c|c|c|c|}
\hline & \multicolumn{3}{|c|}{$\begin{array}{l}\text { Except firms in scientific } \\
\text { research and development }\end{array}$} & \multicolumn{3}{|c|}{$\begin{array}{l}\text { Only firms in scientific } \\
\text { research and development }\end{array}$} \\
\hline & $\begin{array}{c}\text { FE2SLS } \\
(\mathbf{6})\end{array}$ & $\begin{array}{c}\text { RE2SLS } \\
\text { (7) }\end{array}$ & $\begin{array}{c}\text { EC2SLS } \\
(8) \\
\end{array}$ & \begin{tabular}{|c} 
FE2SLS \\
$(9)$ \\
\end{tabular} & $\begin{array}{c}\text { RE2SLS } \\
(10)\end{array}$ & $\begin{array}{c}\text { EC2SLS } \\
(11)\end{array}$ \\
\hline Offshoring (in logs) & $\begin{array}{c}0.137 * * \\
(0.044)\end{array}$ & $\begin{array}{c}0.224 * * * \\
(0.037)\end{array}$ & $\begin{array}{c}0.389 * * * \\
(0.044)\end{array}$ & $\begin{array}{c}0.054 \\
(0.038)\end{array}$ & $\begin{array}{l}0.088 * \\
(0.037)\end{array}$ & $\begin{array}{c}0.108 * * \\
(0.036)\end{array}$ \\
\hline $\begin{array}{l}\text { Domestic innovation expenditures } \\
\text { (in logs) }\end{array}$ & $\begin{array}{c}0.060 * * * \\
(0.005)\end{array}$ & $\begin{array}{c}0.079 * * * \\
(0.005)\end{array}$ & $\begin{array}{c}0.070^{* * *} \\
(0.007)\end{array}$ & $\begin{array}{c}0.139 * * * \\
(0.016)\end{array}$ & $\begin{array}{c}0.174 * * * \\
(0.016)\end{array}$ & $\begin{array}{c}0.170 * * * \\
(0.016)\end{array}$ \\
\hline Wages of researchers (in logs) & $\begin{array}{l}-0.161 * * * \\
(0.011)\end{array}$ & $\begin{array}{l}-0.155^{* * *} \\
(0.011)\end{array}$ & $\begin{array}{l}-0.161 * * * \\
(0.014)\end{array}$ & $\begin{array}{c}-0.188^{* * *} \\
(0.027)\end{array}$ & $\begin{array}{c}-0.192 * * * \\
(0.028)\end{array}$ & $\begin{array}{l}-0.190 * * * \\
(0.029)\end{array}$ \\
\hline Wages of other employees (in logs) & $\begin{array}{c}-0.043^{* * *} * \\
(0.002)\end{array}$ & $\begin{array}{c}-0.043 * * * \\
(0.002)\end{array}$ & $\begin{array}{c}-0.043 * * * \\
(0.002)\end{array}$ & $\begin{array}{c}-0.023 * * * \\
(0.004)\end{array}$ & $\begin{array}{c}-0.021 * * * \\
(0.005)\end{array}$ & $\begin{array}{c}-0.021 * * * \\
(0.005)\end{array}$ \\
\hline Large firm & & $\begin{array}{c}0.346^{* * *} \\
(0.046)\end{array}$ & $\begin{array}{c}0.397 * * * \\
(0.063)\end{array}$ & & $\begin{array}{c}1.904 * * * \\
(0.235)\end{array}$ & $\begin{array}{c}1.892 * * * \\
(0.247)\end{array}$ \\
\hline Exporter & & $\begin{array}{c}0.130 * * * \\
(0.037)\end{array}$ & $\begin{array}{c}0.096 \\
(0.051)\end{array}$ & & $\begin{array}{c}0.336 * * \\
(0.13)\end{array}$ & $\begin{array}{l}0.328^{*} \\
(0.136)\end{array}$ \\
\hline Foreign capital & & $\begin{array}{c}-0.001 \\
(0.074)\end{array}$ & $\begin{array}{l}-0.131 \\
(0.098)\end{array}$ & & $\begin{array}{c}-0.413 \\
(0.290)\end{array}$ & $\begin{array}{l}-0.489 \\
(0.306)\end{array}$ \\
\hline High and medium-tech sector & & $\begin{array}{c}0.238 * * * \\
(0.036)\end{array}$ & $\begin{array}{c}0.262 * * * \\
(0.050)\end{array}$ & & & \\
\hline Hausman (p-value) & & 0.010 & 0.000 & & 0.636 & 0.8615 \\
\hline Test of joint significance & 0.000 & 0.000 & 0.000 & 0.000 & 0.000 & 0.000 \\
\hline $\begin{array}{l}\text { Sargan over-identification test } \\
\quad p \text {-value }\end{array}$ & $\begin{array}{c}\chi^{2}(1)=0.8 \\
0.371\end{array}$ & $\begin{array}{l}\chi^{2}(1)=0.1 \\
0.724\end{array}$ & & $\begin{array}{c}\chi^{2}(1)=0.2 \\
0.635\end{array}$ & $\begin{array}{c}\chi^{2}(1)=2.0 \\
0.161\end{array}$ & \\
\hline Number of observations & 9,560 & 10,220 & 10,220 & 1,685 & 1,705 & 1,705 \\
\hline
\end{tabular}

Source: Own calculation from the PITEC 2004-2009.

Notes: Estimated standard errors between brackets. Coefficients significant at: 1\%***, 5\%**, 10\%*. All regressions include the constant. Hausman reports the $p$-value from a test under the null hypothesis that unobserved firm effects are uncorrelated with the regressors. The test of joint significance of the variables reports the $p$-value of a Wald test except in the case of the FE2SLS estimates, where the $p$-value corresponds to an F-test. The instruments used are: quantity of foreign support for R\&D and international technological cooperation.

Finally, in Table 8 we proceed to estimate the conditional labor demand for researchers (equation [3]) in the manufacturing sector, given that it is the only sector in which we can take the firms' real output into consideration. With this estimation we aim to 
disentangle the presence of the scale effect previously mentioned from the potential complementarity association between R\&D employment and imported R\&D services. As can be seen in Table 8, after adding the output to the specification, the effect of $R \& D$ offshoring on the demand for researchers remains positive and significant, although the elasticity is smaller. This would confirm that they are complements to manufacturing firms.

\section{Table 8}

\section{Conditional demand for researchers (in logs). Manufacturing firms}

\begin{tabular}{|c|c|c|c|c|c|}
\hline & $\begin{array}{l}\text { FE } \\
(1)\end{array}$ & $\begin{array}{l}\text { RE } \\
(2)\end{array}$ & $\begin{array}{c}\text { FE2SLS } \\
\text { (3) }\end{array}$ & $\begin{array}{c}\text { RE2SLS } \\
\text { (4) }\end{array}$ & $\begin{array}{c}\text { EC2SLS } \\
(5)\end{array}$ \\
\hline Offshoring (in logs) & $\begin{array}{c}0.006 * * * \\
(0.001)\end{array}$ & $\begin{array}{c}0.022 * * * \\
(0.002)\end{array}$ & $\begin{array}{c}0.054 * * * \\
(0.012)\end{array}$ & $\begin{array}{c}0.089 * * * \\
(0.010)\end{array}$ & $\begin{array}{c}0.166^{* * *} \\
(0.011)\end{array}$ \\
\hline $\begin{array}{l}\text { Domestic innovation expenditures } \\
\text { (in } \log \text { s) }\end{array}$ & $\begin{array}{c}0.038 * * * \\
(0.002)\end{array}$ & $\begin{array}{c}0.087 * * * \\
(0.003)\end{array}$ & $\begin{array}{c}0.035 * * * \\
(0.002)\end{array}$ & $\begin{array}{c}0.048 * * * \\
(0.002)\end{array}$ & $\begin{array}{c}0.043 * * * \\
(0.003)\end{array}$ \\
\hline Wages of researchers (in logs) & $\begin{array}{c}-0.109 * * * \\
(0.006)\end{array}$ & $\begin{array}{c}-0.095 * * * \\
(0.006)\end{array}$ & $\begin{array}{c}-0.112 * * * \\
(0.005)\end{array}$ & $\begin{array}{c}-0.110 * * * \\
(0.005)\end{array}$ & $\begin{array}{c}-0.115 * * * \\
(0.007)\end{array}$ \\
\hline Wages of other employees (in logs) & $\begin{array}{c}-0.028 * * * \\
(0.001)\end{array}$ & $\begin{array}{c}-0.030 * * * \\
(0.001)\end{array}$ & $\begin{array}{c}-0.028 * * * \\
(0.001)\end{array}$ & $\begin{array}{c}-0.028 * * * \\
(0.001)\end{array}$ & $\begin{array}{c}-0.029 * * * \\
(0.001)\end{array}$ \\
\hline Large firms & & $\begin{array}{l}0.289 * * * \\
(0.018)\end{array}$ & & $\begin{array}{c}0.346^{* * *} \\
(0.030)\end{array}$ & $\begin{array}{l}0.271 * * * \\
(0.042)\end{array}$ \\
\hline Exporter & & $\begin{array}{c}0.016 \\
(0.010)\end{array}$ & & $\begin{array}{l}0.065 * * \\
(0.022)\end{array}$ & $\begin{array}{l}0.062 * \\
(0.029)\end{array}$ \\
\hline Foreign capital & & $\begin{array}{l}0.059 * * \\
(0.017)\end{array}$ & & $\begin{array}{l}-0.023 \\
(0.018)\end{array}$ & $\begin{array}{c}-0.059 * * \\
(0.022)\end{array}$ \\
\hline High and medium-tech sector & & $\begin{array}{l}0.297 * * * \\
(0.010)\end{array}$ & & $\begin{array}{l}0.266^{* * *} \\
(0.019)\end{array}$ & $\begin{array}{l}0.270 * * * \\
(0.024)\end{array}$ \\
\hline Output (in logs) & $\begin{array}{c}0.048 * * * \\
(0.008)\end{array}$ & $\begin{array}{c}0.097 * * * \\
(0.004)\end{array}$ & $\begin{array}{c}0.047 * * * \\
(0.007)\end{array}$ & $\begin{array}{l}0.073 * * * \\
(0.005)\end{array}$ & $\begin{array}{l}0.068 * * * \\
(0.008)\end{array}$ \\
\hline Hausman ( $p$-value) & & 0.000 & & 0.000 & 0.000 \\
\hline Test of joint significance & 0.000 & 0.000 & 0.000 & 0.000 & 0.000 \\
\hline $\begin{array}{l}\text { Sargan over-identification test } \\
\quad \text {-value }\end{array}$ & & & $\begin{array}{c}\chi^{2}(1)=2.5 \\
0.111\end{array}$ & $\begin{array}{l}\chi^{2}(1)=2.0 \\
0.158\end{array}$ & \\
\hline Number of observations & 20,895 & 20,895 & 20,112 & 20,926 & 20,926 \\
\hline
\end{tabular}

Source: Own calculation from the PITEC 2004-2009.

Notes: Estimated standard errors between brackets. Coefficients significant at: $1 \% * * *, 5 \% * *, 10 \% *$. All regressions include the constant. Hausman reports the $p$-value from a test under the null hypothesis that unobserved firm effects are uncorrelated with the regressors. The test of joint significance of the variables reports the $p$-value of a Wald test except in the case of the FE2SLS estimates, where the $p$-value corresponds to an F-test. The instruments used are: quantity of foreign support for $R \& D$ and international technological cooperation. 
To check robustness, we have re-estimated the regressions presented in Tables 4 to 8 using alternative measures for wages and domestic innovation expenditures, but the results remain basically the same. ${ }^{16}$

\section{Conclusions}

The process of offshoring has been done in different ways throughout the years. Before the 1990s, the objective of this strategy was mainly to reduce cost, especially in the manufacturing sector. In the first decade of the new millennium, this phenomenon expanded to services activities, especially with the development of ICTs, the exploitation of new markets, and the development of new products.

Therefore, researches have worried about the causes, effects, and tendencies of this phenomenon. With respect to the studies that seek to analyze the consequences of offshoring on labor markets, one of the main debates has focused on how materials and services offshoring affect the demand for skilled and unskilled workers, or on their impact on wages and welfare.

The objective of our study is to contribute to this debate by analyzing the impact of offshoring on the demand for one of the most qualified workers: researchers involved in $R \& D$ activities. We examine a particular type of offshoring: the purchases of $R \& D$ services that domestic firms contract from foreign providers. These highly technological activities may have a stronger effect on the demand for skilled labor. For the empirical analysis we use firm-level data of Spanish companies for the period 2004-2009 and we quantify the effects of R\&D offshoring within firms that undertake innovative activities.

We find evidence of a positive relation between $R \& D$ offshoring and skilled employment for Spanish firms. In particular, the estimates by instrumental variables procedures suggest that if $R \& D$ offshoring doubles, the demand for researchers will raise by about $8 \%$. This result is consistent with the hypothesis that both inputs are strategic complements, and with the existence of a scale effect: an increase in R\&D

\footnotetext{
${ }^{16}$ In particular, we have considered the average wage for R\&D employment relative to the average wage of workers in the sector in which the firm operates. We have also tried to define domestic innovation expenditures by excluding not only the remuneration of researchers, but also the remuneration of technicians and assistants in R\&D activities. The results are available from the authors upon request.
} 
offshoring would make the firm more efficient, increasing the demand for its product and for all types of employment. This conclusion is also in line with previous empirical evidence with industry-level data suggesting that service offshoring increases high skilled employment (Crinò, 2010).

In addition, we find that the elasticity in services firms is double the elasticity in manufacturing firms. However, as we would expect given the specific type of offshoring considered in this study, the magnitude of the elasticity is lower in the subsample of services firms performing $R \& D$ activities. In this case, the scale effect could be partially compensated by a substitution relation between both inputs.

From our view, governments should be aware that $R \& D$ offshoring by services and manufacturing firms is not a threat but an opportunity; because of its complementarity with high skilled labor, which can be capitalized as long as public policies include programs to retrain and qualify the workforce to perform the required tasks. 


\section{References}

Amiti, M. and Wei, S.-J. (2005a): "Fear of service outsourcing: Is it justified?", Economic policy 20(42), 308- 347.

Amiti, M. and Wei, S.-J. (2005b): "Service offshoring, productivity, and employment: Evidence from the United States", IMF Working Papers 05/238, International Monetary Fund. Washington, DC.

Amiti, M. and Wei, S.-J. (2006): "Does service offshoring lead to job losses? Evidence from the United States", NBER Chapters, in: International Trade in Services and Intangibles in the Era of Globalization, National Bureau of Economic Research, Inc.

Antras, P. and Helpman, E. (2004): "Global Sourcing”, Journal of Political Economy $112(3), 552-80$

Añon, D., Driffiel, N and Temouri, Y. (2010): "The futures of Offshoring FDI in hightech sectors", Futures 42, 960-970.

Baltagi, B.H. (2008), Econometric Analysis of Panel data, Fourth Edition, Chichester: John Wiley.

Bernand, A.J. et al. (2007): "Firms in International trade", NBER Working paper No 13054.

Bulow, J. and Summers, L. (1986): “A Theory of Dual Labor Markets, with Applications to Industrial Policy, Discrimination, and Keynesian Unemployment", Journal of Labor Economics 4, 376-414.

Canals, C. (2006): "Outsourcing and your Collar's Color", Working Paper Series No. 03/2006, La Caixa.

Crinò, R. (2010): "Service offshoring and white-collar employment", Review of Economic Studies 77(2), 595-632.

Criscuolo, C. and Garicano, L. (2010): “Offshoring and Wage Inequality: Using Occupational Licensing as a Shifter of Offshoring Costs", American Economic Review, May (2), 439-443. 
Ekholm, K. and Hakkala, K. (2006): "The effect of offshoring on labor demand: Evidence from Sweden", CEPR Discussion Papers 5648, C.E.P.R. Discussion Papers.

Feenstra, R (2004): Advanced International Trade, Theory and Evidence, Ed Pricenton University Press.

Feenstra, R. (2007): "Globalization and its impact on labour", wiiw Working Paper Series No.44, The Vienna Institute for International Economic Studies.

Feenstra, R. (2010): Offshoring in the Global Economy: Microeconomic Structure and Macroeconomic Implications, The MIT Press, Cambridge, Massachusetts.

Feenstra, R. and Hanson, G. (1999): “The impact of Outsourcing and High Technology Capital on Wages: Estimates for the United States, 1979 - 1990”, Quarterly Journal of Economics 114, 907-940.

Geishecker, I. (2006): "Does outsourcing to Central and Eastern Europe really threaten manual workers' jobs in Germany?", The World Economy 29(5), 559-583.

Geishecker, I. and Görg, H. (2008): "Winners and losers: A micro-level analysis of international outsourcing and wages", Canadian Journal of Economics 41(1), 243270.

Geishecker, I. and Görg, H. (forthcoming): "Services offshoring and wages: Evidence from micro data", Oxford Economic Papers, doi:10.1093/oep/gpr055.

Glass, A and Saggi, K. (2001): "Innovation and wage effects of international outsourcing”, European Economic Review 45, 67-86.

Griffith, R., Harrison, R. and Van Reenen, J. (2006): "How special is the special relationship? Using the impact of U.S. R\&D spillovers on U.K. firms as a test of technology sourcing", The American Economic Review 96(5), 1859-1875.

Griliches, Z. (1979): "Issues in assessing the contribution of R\&D to productivity growth", Bell Journal of Economics 10, 92-116.

Griliches, Z. (1995): "R\&D and productivity: econometric results and measurement issues". In: Stoneman, P. (Ed.), Handbook of Economics of Innovation and Technological Change. Blackwell, Oxford, pp. 52-89. 
Grossman, G. and Helpman, E. (1991): “Quality ladders and product cycles”, Quarterly Journal of Economics 106, 557-586.

Grossman, G. and Rossi-Hansberg, E. (2008): “Trading Task: A Simple Theory of offshoring”, The American Economic Review 98(5), 1978-1997.

Hamermesh, D.S. (1980): "Commentary", in J. J. Siegfried (ed.): The Economics of Firm Size, Market Structure and Social Performance. Washington D.C.: Federal Trade Commission.

Hamermesh, D.S. (1993): Labor Demand. Princeton, NJ: Princeton University Press.

Helpman, E. and Krugman, P.R. (1985): Market Structure and Foreign Trade. Cambridge, MA: The MIT Press.

Hijzen, A., Görg, H. and Hine, R.C. (2005): "International Outsourcing and the Skill Structure of Labor Demand in the United Kingdom”, Economic Journal 115, 860-78.

Jensen, P. (2009): “A learning perspective on the offshoring of advance service", Journal of international Management 15, 181 - 193.

Kremer, M. (1993): “The O-Ring Theory of Economic Development”, The Quarterly Journal of Economics 108, 551-75.

Mayer, T. and Ottaviano, G. (2008): “The Happy Few: The internationalization of European Firms", Intereconomics: Review of European Economic Policy 43(3), 135-148.

Metters, R. and Verma, R. (2008): "History of offshoring knowledge services", Journal of Operations Management 26, 141-147.

OECD (2007): Offshoring and Employment. Trends and Impacts.

OECD (2010): OECD Economic Globalisation Indicators.

OECD (2011): OECD Perspectives: Spain Policies for a sustainable recovery.

Trefler, D. (2005): "Service offshoring: Threats and opportunities", Brookings Trade Forum 35-60. 
Annex 1: Sector Classification

Correspondence of low-tech and high \& medium-tech activities and the two-digit NACE Rev. 2 class

\begin{tabular}{|c|c|}
\hline NACE Rev. 2 & Low-tech manufacturing \\
\hline $10-12$ & Food, beverages and tobacco \\
\hline 13 & Textile \\
\hline 14 & Wearing apparel \\
\hline 15 & Leather and footwear \\
\hline 16 & Wood and cork \\
\hline 17 & Paper and paper products \\
\hline 18 & Printing and reproduction of recorded media \\
\hline 19 & Coke and refined petroleum products \\
\hline 22 & Rubber and plastic products \\
\hline 23 & Other non-metallic mineral products \\
\hline 24 & Basic metals \\
\hline 32 & Other manufacturing \\
\hline 31 & Furniture \\
\hline \multirow[t]{2}{*}{33} & Repair and installation of machinery and equipment \\
\hline & High \& medium-tech manufacturing \\
\hline 20 & Chemicals and chemical products \\
\hline 21 & Pharmacy \\
\hline 25 & Metal products (except machinery and equipment) \\
\hline 26 & Computer, electronic and optical products \\
\hline 27 & Electrical equipment \\
\hline 28 & Machinery and equipment n.e.c. \\
\hline 29 & Motor vehicles, trailers and semi-trailers \\
\hline \multirow[t]{2}{*}{30} & Other transport equipment \\
\hline & Low-tech services \\
\hline $45-47$ & Wholesale and retail trade; repair of motor vehicles and motorcycles \\
\hline $49-53$ & Transportation and storage \\
\hline $55-56$ & Accommodation and food service activities \\
\hline $64-66$ & Financial and insurance activities \\
\hline 68 & Real estate activities \\
\hline $69-71,73-75$ & Other activities (except R\&D services) \\
\hline $77-82$ & Administrative and support service activities \\
\hline 85 (except 854) & Education \\
\hline $86-88$ & Human health and social work activities \\
\hline $90-93$ & Art, entertainment and recreation \\
\hline \multirow[t]{2}{*}{$95-96$} & Other service activities \\
\hline & High \& medium-tech services \\
\hline $58-63$ & Information and communication \\
\hline 72 & Scientific research and development \\
\hline
\end{tabular}

